\title{
On Sexism in Language and Language Change - The Case of Peninsular Spanish*
}

\author{
Benedicta Adokarley Lomotey (Legon, Ghana)
}

\begin{abstract}
The Spanish language has been described as a sexist language due to the peculiar characteristics of its gender morphology. It is indicated by the $o$ ('masculine') and $a$ ('feminine') gender morphemes which generally represent male and female respectively. This has led to an apparent confusion between grammatical gender and biological sex.

Against this background, this paper attempts to discover the impact of anti-sexist language proposals on the Spanish language by analyzing sample Spanish newspapers. Of the 40 articles analysed from 20 representative newspapers, findings suggest that although some antisexist language elements have been adopted, their usage is erratic and the masculine generics are still used extensively. The results suggest that despite the challenges facing language reform attempts, the reinforcement of positive language policies is possible.
\end{abstract}

\section{Introduction: language and sexism}

Language is present in all human activities. It plays an important role in society due to its communicative functions but it also reflects a multitude of characteristics of each linguistic community. One such socio-cultural manifestation in language which has been the subject of debates for decades is gender discrimination in language. The Spanish language in particular has been described as a sexist language (cf. Eisenberg 1985; Calero Fernández 1999; Bengoechea 2011) due to the existence of grammatical gender. Even though other languages (especially the Romance Languages) also have grammatical gender, the morphology of gender in Spanish has peculiar characteristics. It is indicated by the $o$ ('masculine') and $a$ ('feminine') gender morphemes which generally represent male and female respectively. This has led to an apparent confusion between grammatical gender and biological sex.

One observes an interesting dichotomy in the debate on the existence of linguistic sexism. For example, Díaz Rojo (2000: 43-44) asserts that "concepts, principles or beliefs can influence the meaning of some words, in the creation of new vocabulary or through metacategorization" and language can be a vehicle of sexism, but languages "do not discriminate against anyone" because "the same way that a language cannot be conservative, nor socialist, nor liberal... neither can it be sexist, nor racist, nor xenophobic... ".

\footnotetext{
* This article is an extract from an ongoing doctoral thesis which is being undertaken at the Universidad Nacional de Educación a Distancia (UNED), Madrid, Spain.
}

Linguistik online 70, 1/15 - http://dx.doi.org/10.13092/lo.70.1748

CC by 3.0 
However, other scholars (cf. Wasserman/Weseley 2009) have maintained that linguistic sexism does exist. These authors postulate that as the Sapir-Whorf hypothesis affirms, linguistic discrimination does influence the worldview and behavior of language users. Of particular interest to this study is Prewitt-Freilino, Caswell and Laakso's (2012: 278) argument that it seems that countries that speak gendered languages have less gender equality than countries where natural gender or genderless languages are spoken.

Scholars such as Eisenberg (1985), Calero Fernández (1999) and Jiménez Rodrigo, Onsalo and Cortes (2011) have attributed sexism in Spanish to the patriarchal culture of the Spaniards. Furthermore, feminists have described language and discourse as "a powerful instrument of patriarchy" (Pauwels 1999: 1). Pauwels (2003: 550) also affirms that for centuries men have played the role of norm-makers, language regulators, and language planners and have "signaled their authority in language through their roles in the dictionary-making process, in the writing of normative grammars, in the establishment of language academies and other normative language institutions, and through their involvement in language planning activities". On the other hand, women had a certain authority in the regulation of language "as norm enforcers: both as mothers and as school teachers (especially in elementary education)..." (ibid.). As Fairclough (1989: 3) affirms, language cannot be ignored in issues about the relationships of power in modern society.

Linguistic sexism seems to provide strong evidence of the Sapir-Whorf hypothesis which states that language constrains and shapes our thoughts and perceptions (cf. Heredero 2007: 88). Lemus (2001: 8) rightly describes the claims of linguistic sexism and the merits of language reform as a "very specific version of the Sapir-Whorf hypothesis".

\section{Tradition and Language Reform: an overview of the debates on sexist language change in Spanish and other languages}

Starting from the 1970s in the United States and then England, radical feminists began to fight against linguistic androcentrism because they argue that sexist language influences the thoughts of speakers and thus contributes to the perpetuation of discrimination against women. They also postulate that there is an interconnection between women's social position and gender asymmetries in language (cf. Heredero 2007; Lakoff 1995). Lemus (2001: 8) describes these affirmations as a hypothesis which he calls "Hipótesis del Idioma Sexista" (the Hypothesis of Sexist Language). In Spain, these language reform activities started in the 1980s (cf. Nissen 2002; Francesconi 2012).

Areas of the Spanish language in which sexism has been identified are in the grammatical system, the lexicon and the discourse. This paper focuses on gender and sexism in the Spanish grammatical system. Of particular interest is the generic use of the masculine gender. Hellinger and Bußmann (2002: 14) describe pronominalization as a "powerful strategy of communicating gender". Thus, with the presence of this possibility in Spanish, this area of linguistic sexism becomes an interesting area of focus. 
Proposed non-sexist recommendations include:

i. Propagation of the feminization of words that refer specifically to women.

ii. Replacement of the masculine form for generic reference by epicene words or by splitted constructions.

iii. Avoidance of certain asymmetrical words. e. g. señorita 'miss' should be replaced by señora and hombre 'man' by humanidad 'humanity' or ser humano 'human being' (cf. Nissen 2002: 270).

Many proposals for language reform have been published in order to enable the emancipation of women and gender equality. Guerrero Salazar (2007) has identified a series of guidelines, published between 1986 and 2006, by town councils, regional administrations, the national government, trade unions and semi-public organizations such as savings banks. Other nonsexist proposals have been recommended by a variety of bodies including the Terminology Committee appointed by the Committee for the Equality of Men and Women of the Council of Europe (1986), the Equality Department of the autonomous regions of Valencia (Departamento de la Dona 1987) and of the Basque Country (Emakunde Instituto Vasco de la Mujer 1988), the Ministerio de Educación y Ciencia (1988), Instituto de la Mujer (1989) and UNESCO (1990). The following recommendation by the Committee for Equality between Women and Men of the Council of Europe is an example of relevant legal measures that have been put forward by various sectors:

The Committee of Ministers ... Convinced that the sexism characterising current linguistic usage in most Council of Europe member States - whereby the masculine prevails over the feminine - is hindering the establishment of equality between women and men, since it obscures the existence of the women as half of humanity, while denying the equality of women and men; [sic!] Noting also that the use of the masculine gender to denote people of both sexes is, in today's social context, a source of uncertainty about the people - men or women - involved; ... Recommends that governments of member States promote the use of a language reflecting the principle of equality of the women and men and, take all measures they consider appropriate with a view to: 1 . encouraging the use, as far as possible, of non-sexist language to take account of the presence, status and role of women in society as current linguistic practice does for men; 2. bring the terminology used in legal drafting, public administration and education into line with the principle of sex equality; 3. encourage the use of non-sexist language in the media.

(Council of Europe 1990 quoted in Bengoechea 2011: 35f.)

The objectives of these Anti-Sexist Language (henceforth ASL) guidelines (cf. UNESCO 1990; Calero Fernández 1999; Ayala/Guerrero/Medina 2002; etc.) are laudable. However, one is confronted with the controversial nature of these attempts given that they "contravene not only the norms of the Spanish Royal Academy (henceforth RAE) and the Association of Academies, but also those of various grammatical rules, as well as those of several language guides written in recent years by very diverse mediums of communication" (Bosque 2012: 1). Subsequently, the Spanish Royal Academy, established to promote the "good usage of the Spanish language", has made various pronouncements against these reform attempts.

In particular, it has spoken against the use of the collective, abstract or metonymical names (e. g. Ciudadanía 'citizenry' in place of ciudadanos 'citizens-MASC'); and profesorado 'teaching staff' in place of profesor 'teacher-MASC'. In addition, the RAE insists on the generic value of the masculine gender. Consequently, many proposed anti-sexist alternatives to the generic masculine, such as the dual forms and the@ symbol, are considered as "incorrect 
grammatical forms" by the RAE and other important language institutions such as the Asociación de Academias de la Lengua Espanola (Association of Academies of the Spanish Language). The majority of the criticisms posed by anti-reform campaigners worldwide have been summarized and analyzed by Blaubergs (1980) and Pauwels (1998).

Fairclough (1989: 2) affirms that "language contributes to the domination of some people by others" and "consciousness is the first step towards emancipation". Consequently, the importance of eliminating linguistic sexism remains clear. However, it is less clear how this can be achieved and what the eventual implications of these feminist attempts would be. It is thus imperative to investigate the effects of feminist proposals on the Spanish language because of its socio-cognitive relevance and the possible pragmatic difficulties it evokes. In addition, studies of the extent to which linguistic reform proposals have been accepted or rejected are necessary due to the resistance against language reform. Such studies are needed to identify and eliminate possible obstacles to the implementation of ASL policies. Much research has been done on linguistic sexism in Spanish (cf. Lledó 1992; García Meseguer 1994; Díaz Rojo 2004; Roca 2006 etc.). However, the same cannot be said for non-sexist language reform.

Of the existing studies on the extent of non-sexist Spanish, the work of Bengoechea and Simón (2014) is important. These authors investigate the attitudes of university students to non-sexist linguistic policies. They conclude that university students have a positive attitude which may suggest some success in the spread and adoption of the recommended anti-sexist alternatives (cf. ibid.: 88). Nissen $(2002,2013)$ also studies the cognitive and attitudinal understanding of generic masculine in Spanish. He evaluates the interpretation of genderspecific and gender-neutral expressions and asserts that "surprisingly", the masculine form seems to promote a greater amount of gender neutrality while the dual form is the best approach for achieving female visibility (cf. ibid. 2013: 112-114). He reports that "with respect to the masculine and the gender neutal form, the gender bias (towards male) has decreased, with respect to the dual form it has increased (towards female)" (ibid.: 113).

Despite the time difference between Nissen's study (2013) and that of Perissinotto (1983), it is important to point out the contradiction between Nissen's conclusions and that of Perissinotto. The latter affirms that "one can safely argue that the case for the generic masculine is rather weak in Spanish" (1983: 585). Perhaps, this conflict goes to support Nissen's finding that women have probably become more visible within the time span investigated in his study.

Jiménez Rodrigo, Onsalo and Cortes (2011) also evaluate the perception and beliefs about anti-sexist language as well as the possible barriers to the adoption and success of these recommended gender-neutral forms among university students. Other interesting studies are those of Bengoechea (2006, 2008), Velasco, Vázquez and Ibáñez (2009), Rodríguez Fernández (2009) and Centenera Sánchez-Seco (2010). Nonetheless, very few of these studies, however, provide a quantitative analysis on the extent of the usage of non-sexist Spanish. For example, Rodríguez Fernández (2009) compares the use of generic masculines in sample articles taken from two newspapers; one from 1976 and the other from 2006, and four magazines published in the years 1988 and 2006. She finds that the plural masculine generic is still used abundantly in 2006, when compared with 1976. She also identifies a reduction in the usage of the singular masculine generic and an increase in the use of non-sexed nouns in both newspapers. In the magazines she detects a decrease in the use of both the singular and the plural 
masculine generic and an increase of gender-neutral nouns. Although she provides a very important comparative study, she does not offer any quantitative analysis in her study.

\section{$3 \quad$ Objectives}

This study seeks to contribute to existing research on the adoption and/or rejection of antisexist alternatives from both a qualitative and quantitative perspective. In doing so, the paper will examine the impact of ASL proposals on the Spanish language and the possible drawbacks of language reform activities. Specifically, this research sought to:

1) Determine which variety of the Spanish language (sexist or non-sexist) speakers used more frequently

2) Establish which variety was used in more formal contexts and which was used in more informal contexts

3) Evaluate the regularity of the use of anti-sexist language

Two broad criteria were selected for the analysis: the generic use of the masculine gender and the use of anti-sexist language. The research questions which formed the basis for this study were the following:

i. Is ASL being adopted?

ii. Are there any patterns in the use of anti-sexist language?

iii. Do men use sexist language more than women?

These research questions led to the following three hypotheses:

a. ASL is used in formal contexts and sometimes in semi-formal contexts.

b. The use of ASL is irregular.

c. Both women and men use sexist language.

\section{$4 \quad$ Method}

Some quantitative research methods were used in the present study. However, this paper is predominantly a small-scale qualitative research that uses limited data. While this poses some obstacles, the sample size was chosen after carefully taking the law of diminishing returns (Kvale 2008: 44) into consideration. A description of the method used is provided below.

\subsection{Selection, collection and description of materials}

Fourty extracts from 20 Spanish newspapers were analyzed. The newspapers were El Pais, La Nueva España, La Voz, y El periódico de Aragón, among others. The extracts were selected from a list of all the regional newspapers in Spain. Due to the importance of having a good representation, these newspapers were then carefully categorised: one for each autonomous community of Spain, the two autonomous cities (Ceuta y Melilla) and a national newspaper (el País).

In order to analyse the use of ASL in formal and semi-formal contexts, two extracts were selected from each newspaper. Thus, from each newspaper an extract was selected from the "opinion" section and another from the "news" section using the criteria that it should have a political or social theme. Whilst the extracts were broadly selected, it was necessary to identi- 
fy those that had quite a number of nouns referring to human referents in order to obtain a corpus illustrative of the use of the grammatical gender in natural speech contexts. All the extracts were selected with care in order to obtain uniformity in political or social themes. Also, the selected newspaper articles in the corpus were numbered and in the analysis they will be referred to numerically. These newspapers were downloaded from their corresponding websites.

The analysis was carried out focusing on the use of grammatical gender in animate nouns. The nouns were those with split forms (amigo/amiga) and those with a common gender. The study also aimed at analysing the generic use of the masculine gender.

In order to identify the influence of feminist linguistics on the Spanish language, the following ASL proposals by Ayala, Guerrero and Medina (2002: 49-57, my translation, L.B.) were examined.

a) Collective or generic nouns, e. g. La plantilla de la empresa 'the staff of the company' instead of los trabajadores 'the workers-MASC'.

b) Periphrasis, e. g. la clase politica 'the political class' instead of los politicos 'the politicians-MASC'.

c) Metonymic constructions, e. g. la gerencia 'the management' instead of los gerentes 'the directors-MASC'.

d) Split forms, e. g. Los trabajadores y las trabajadoras 'the workersMASC' and 'the workers-FEM'.

e) Slash sign, e. g. Impreso para el/la cliente/a 'printed for the clientMASC/the client-FEM'.

f) Explicative appositions, e. g. El objetivo es proporcionar a los jóvenes una formación plena 'the objective is to provide full training for the youth (male or female)'. Proposed change: El objetivo es proporcionar a los jóvenes, de uno y otro sexo, una formación plena 'the objective is to provide the youth, of one and the other sex, a full training'.

g) Omission of determinants, e. g. Podrán optar al concurso los profesionales con experiencia 'Professionals-MASC/FEM with experience can apply for the competition'. Proposed change: Podrán optar al concurso profesionales con experiencia 'Professionals with experience can apply for the competition'.

h) Determinants without gender marking, e. g. Cada miembro recibirá 'each member will receive' instead of Todos los miembros recibirán 'all the members will receive'.

i) Structures with se, e. g. Se decidirá judicialmente 'it will be decided judicially' instead of El juez decidirá 'the judge-MASC will decide'.

j) Certain personal forms of verbs, e. g. Si el usuario decide abandonar la zona antes de lo estipulado, debe advertirlo 'if the user-MASC decides to leave the zone before the stipulated time he or she should give notice'. Proposed change: Si decide abandonar la zona antes de lo estipulado, debe advertirlo 'if it is decided to leave the zone before the stipulated time notice should be given'.

k) Impersonal forms of verbs, e. g. Es necesario que el usuario preste más atención 'it is necessary that the user-MASC pays more attention'. Proposed change: Es necesario prestar más atención 'it is necessary to pay more attention'. 
To analyze the data in the present study, frequency counts and techniques of linguistic analysis were employed. The quantitative method enabled a statistical study while the qualitative method helped identify the nuances of the difficulties of language reform. The frequency count was achieved using the AntConc Concordancing Programme. It helped to identify the frequency of the use of ASL elements as manifested in the use of peninsular Spanish by journalists and article contributors. Moreover, percentage figures were used to demonstrate the distribution of anti-sexist elements. The linguistic analysis was done from structural and semantic perspectives.

The use of this combination of methods and techniques (corpus linguistics, text analysis and linguistic analysis) enabled the study of naturally occurring language.

\section{$5 \quad$ Results}

The total number of word types was 5.925 while the total number of word tokens was 24.256. This data was adequate for the aim of the research which was to investigate the influence of ASL on Spanish through naturally occurring corpus. Words and expressions which would generally be tagged as sexist abounded in the articles examined. Some of the words which appeared most frequently in the masculine generic form were ciudadanos 'citizens', españoles 'spaniards', empleados 'employees', amigos 'friends', padres 'parents', hijos 'children', funcionarios 'workers', hombre(s) 'mankind', jóvenes 'youth', lector 'reader' and politicos 'politicians'.

The frequency of these expressions was calculated in two parts. The nouns with double forms were counted first. After that, those with common forms were also counted. For the first group, the total number of word types was 125 and there were 617 word tokens. In other words, the double-form nouns used in the masculine generic sense (125) appeared 617 times. On the other hand, the anti-sexist expressions appeared only 56 times. It is important to consider that even in these cases it was not always clear whether the writer chose these expressions because she or he wanted to avoid sexist terms. For example:

Las redes sociales son lo mejor que han inventado nunca. Yo no puedo vivir sin ellas [...] No hace falta irse a la puerta de un colegio para escuchar estas frases de chicos y chicas que han cambiado las revistas porno y la Súper Pop, (¿No es lo mismo?), por las tabletas digitales (Artículo 13).

'The social networks are the best inventions ever. I can't live without them. [...] One doesn't need to go to a school entrance to hear these sentences from boys and girls who have changed pornographic and super pop magazines, (is it not the same?), for digital tablets (Article 13)'.

(Segalás: 2013)

In this example, it is not easy to determine whether the expression chicos y chicas 'boys and girls' is an attempt to avoid linguistic sexism. This is because it could also be the result of a desire to emphasize that both girls and boys are addicted to Facebook and Twitter. To sum up the findings of the present study in percentages, the ASL variety came to a total of $7 \%$ while the usage of the sexist language variety was $93 \%$ (See figure 1). The findings of the present linguistic analysis can be synthesized as follows: 


\section{Sexist and Non-Sexist Linguistic Variants}

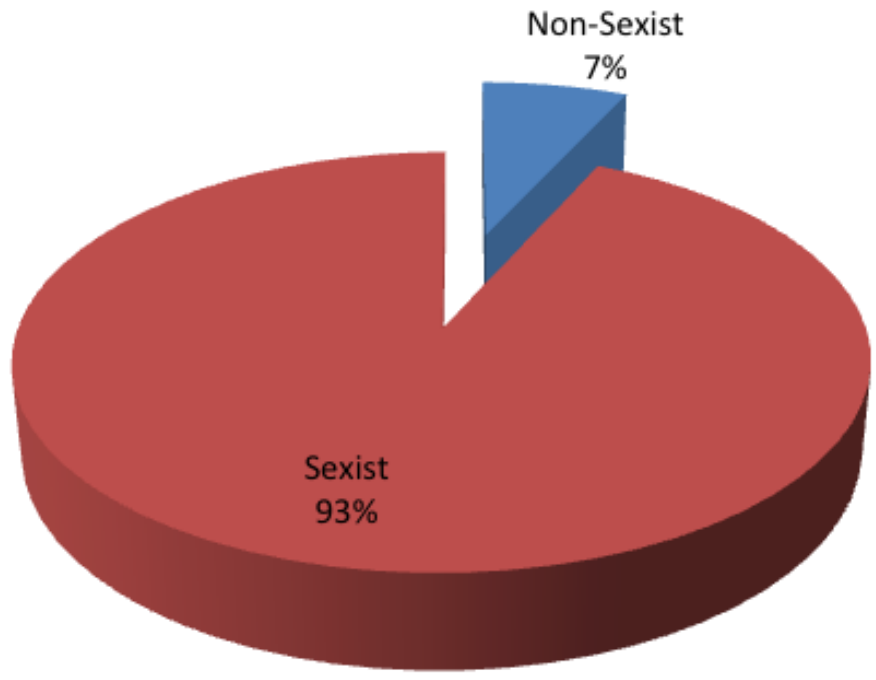

Figure 1. Distribution of sexist and non-sexist linguistic variants in corpus of data analysed.

\subsection{Frequency in usage of variants}

The analysis revealed that the masculine generic form is probably used with a greater and more significant frequency than the anti-sexist alternatives. The frequency of the sexist variants was 93\%. There were 617 split nouns and 151 common gender nouns that were used in sexist forms. In the case of anti-sexist variants only 56 instances (7\%) were found. The minimal use of non-sexist variants in this study suggests that speakers were reluctant to reform their language on the grounds of it being sexist. These results seem to echo Nissen's affirmation that "... at present, the findings for Spanish mean that the recommendation to avoid the masculine form on the grounds of it being male biased cannot be supported statistically" (2013: 113).

The anti-sexist forms which appeared most regularly were the split forms (chicos y chicas 'boys and girls'), the collective and abstract nouns (la ciudadania 'the citizenry') and words with non-marked gender forms (persona 'person'). It could be the case that speakers used the sexist variety more frequently because they are considered to be 'normal'. Apparently, it is not easy to adhere to these logical changes in communication since language is more instinctive than calculated. In addition, the complicated nature of the split forms makes it an unlikely candidate for anti-sexist alternatives (cf. Roca 2006; Bosque 2012).

On the other hand, suggestions such as the use of the slash (/) and the dash (-) were not found in any of the articles. Nissen (2002: 271) describes the @ symbol as the "the most economical alternative which is likely to spread most rapidly". However, it does not appear in any of the sample texts. This indicates that they have limited use and appear in less formal contexts. That said, they do seem to be penetrating the Spanish language slowly. For example, in a first year beginners' Spanish grammar class that the researcher took, a student asked why the @ symbol had not been mentioned as a variant of the $a$ and $o$ gender morphemes. It is important 
to point out that these forms have been criticised extensively by the RAE because they conflict with normative Spanish grammar (cf. Bosque 2012: 1).

\subsection{Context of usage of variants}

The study of the selected corpus showed that the varieties used are not restricted to any register or context. As earlier indicated, the newspaper articles extracted for analysis had an equal distribution between formal contexts and semi-formal contexts. Articles belonging to the former had both political and social themes. Those belonging to the semi-formal had predominantly social themes and were extracted from the opinion section of the newspapers. Thus, both articles from the "opinion" and "news" sections had elements of sexist and anti-sexist language features. Nonetheless, closer analysis revealed that the anti-sexist alternatives are largely used in formal contexts, and particularly in political discourses. Thus, of the 56 instances of non-sexist variants found, $23(41 \%)$ were identified in political contexts. The remaining $33(59 \%)$ were from other contexts that either did not necessarily have political themes or belonged to the semi-formal contexts.

This is probably a result of the anti-sexist linguistic policies introduced by some autonomous, national and international institutions and agencies to promote the use of gender-neutral verbal elements. These measures have influenced the use of Spanish in political and administrative sectors, probably because it is incumbent on those found in these positions to respect public sensibilities. It might be suggested that the ASL rules and policies decreed by various institutions have influenced the choice of language users who choose ASL varieties occasionally. This is especially true in formal contexts, relating to administration or politics.

However, the masculine generic was also used constantly in these formal contexts. No pattern was found in the use of sexist and anti-sexist varieties. Both elements of ASL and sexist language were identified in the extracts taken from the opinion section of the newspapers selected. For example the generic use of the feminine gender amigas 'friends (female)' in article 13 appeared with other uses of the masculine generic. In the same manner, some sexist language and anti-sexist language features were also identified in the extracts taken from the news columns. Overall, the analysis suggests that there is a dominant use of the masculine generic as can be observed in the following examples:
a. los españoles, los trabajadores (articles 9, 10, 12, 20 etc.)
b. los políticos, los hombres, los ciudadanos, los conciudadanos, los padres, los hijos, los hermanos, los amigos, los miembros, los jóvenes, los niños (which appear in articles 1, 3, 32, 5, 7, 11, 17, $22,23,25,26,27,28,29,30,31,35,37,39$ and 40).
c. The words hombre, lector and politico in the singular masculine generic form appear in articles 39, 29 and 17 respectively.

This tendency was identified in sentences such as these:

a. $\quad$ "Los psiquiatras recomiendan a los padres 'preocuparse' cuando cambia el funcionamiento académico habitual del chico" ('Psychiatrists recommend that parents 'worry' when the habitual academic performance of the child (daughter or son) changes') (article 22). 
b. $\quad$ "Si un trabajador es despedido [...] y el juez declara el despido improcedente, no existe la obligación de readmitir al trabajador, como lo saben miles de trabajadores que lo han sufrido en España" ('If a worker -male or female- is fired [...] and the judge (male or female) declares the dismissal to be inadmissible, there is no obligation to reemploy the worker (male or female), as thousands of workers who have experienced it in Spain already know'] (Article 9).

Moreover, it would have been expected that compound words refering to associations or groups, would reflect the real influence of ASL campaigns. Since they are fixed expressions which are used frequently in a variety of contexts and by different people, feminist language activities were expected to influence these areas. However, the texts analysed revealed a consistent use of the masculine generics even in these cases. The following examples are names of associations extracted from the corpus to illustrate this point:
a. $\quad$ El Estatuto de los Trabajadores 'Workers' (male or female) Statutes' (article 9)
b. Congreso de los Diputados 'Congress of Members of Parliaments (male or female)' (article 10)
c. Colegio de Abogados de Barcelona 'Bar Association of Barcelona (male or female)' (article 10)
d. La Plataforma de Afectados por la Hipoteca 'Mortgage Victims' Platform (male or female)' (article 18)
e. $\quad$ Proyecto Hombre 'Project Man' (article 19)
f. La Asociación de Vecinos Carmen Amaya 'The Association of Carmen Amaya Neighbours (male or female)' (article 20)
g. La Asociación Española de Psiquiatría del Niño y el Adolescente 'Spanish Association of Child and Adolescent (male or female) Psychiatry' (article 22)
h. $\quad$ Asociación de los Cuerpos Superiores de Letrados y Auditores del Tribunal de Cuentas 'Association of the Governing Body of Attorneys (male or female) and the Spanish Court of Auditors' (article 24)

Thus, it could be concluded that while the ASL variety is used most often in the formal contexts, none of the varieties are restricted to a specific context. In the majority of contexts the masculine generic form coexists with the non-sexist alternatives. An illustrative case was found in article 13 in which the generic use of the feminine gender amigas 'friends' and the singular form of the masculine generic (no se puede peor hijo 'no child could be worse'), are both identified.

Also, the contrast can be observed in the phrase "Más de quince mil personas que no han podido pagar la renta o la hipoteca y que, como Miguel, han sido arrojados a la calle." ('More than fifteen thousand people who have not been able to pay their rent or mortgage and who, like Miguel, have been thrown into the streets.') (article 20). The non-sexist variants are thus used in a sporadic and inconsistent manner in both semi-formal and formal contexts. Bengoechea (2011: 47) asserts that it is a "tendency that coexists with an abundance of masculine generic forms, often in the same text". This same tendency can be detected in the majority of 
articles studied where an abundance of the masculine generic and in some cases sporadic antisexist varieties were identified.

\subsection{Regularity in the usage of anti-sexist variants}

It was observed that ASL is used in a sporadic and inconsistent way and no regularity in usage could be identified. As Bengoechea (2011: 40) notes: "Not only do very few speakers use the variety, and then only occasionally in oral formal addresses, informal letters and e-mail greetings, political campaigns [...]. In most cases, if used at all, it is unsystematic and intermittent". Due to the low frequency and lack of robustness in the use of the ASL variety, it appears that future possibilities for the use of this variety are somewhat negative. Apart from the conflict between feminist linguists and the RAE, there are other difficulties that hinder the proliferation and the diffusion of the ASL proposals. One such problem is the pragmatic complexity that arises from attempting to apply these ASL guidelines. Grice's Cooperative Principle (1967/1989) and Sperber and Wilson's (1986/1995) relevance theory further explain the intricacy of this problem.

Though the articles were not distributed in equal numbers between male and female writers, it was discovered that both sexes use the masculine generic form. It was thus impossible to find any patterns in the use of the two varieties according to the writer's sex. For example, article 13, had the most interesting anti-sexist feature, namely the generic use of the female gender. Yet it was written by a man (Alejandro Segalás). On the other hand, article 22 contained extensive generic forms of the masculine gender. However, it was written by a woman (Amaia Mauleón-Vigo). Article 31 was written by Elsa López and has a very anti-chauvinistic tone. It portrays nuances of feminist ideologies but contains the universal usage of the masculine gender:

Los diseñadores, esa extraña fauna que nunca piensa en las mujeres llamadas al sacrificio de la vanidad... y ... De ellas son los cuerpos que desfilan o reposan con la obligada posición del esclavo condenado a ser objeto de culto...

'The designers [male or female], that strange fauna that never thinks about the women who have to sacrifice themselves to vanity... and ... Theirs are the bodies that parade or repose with the obligatory position of the slave [male or female] who is condemned to be the object of worship'.

(López: 2013)

\section{$6 \quad$ Summary and Discussion}

This paper has sought to study the impact of ASL campaigns on the Spanish language through a linguistic analysis of newspaper extracts. It had three objectives. To examine 1) the linguistic variety (sexist or non-sexist) that speakers use more frequently; 2) the variety which appears more in formal contexts and that which is used more often in informal contexts and 3) the regularity of the use of anti-sexist language. Before reviewing the results of the study it is worth emphasizing that the data are, strictly speaking, only valid for the chosen group of newspaper samples analysed.

From the analysis, it can be concluded that 1) both the sexist and non-sexist varieties are used, though the sexist variants have a higher frequency while usage of the anti-sexist variants is lower and intermittent 2) although both variants can be found in both formal and non-formal contexts, the anti-sexist alternatives have a tendency to appear in the more formal contexts 
(political, administrative, etc.); 3) the use of ASL in the samples analysed was irregular and mostly coexisted with the sexist variants.

These findings suggest that attempts at language reform have been somewhat successful. Indeed, language reform attempts have come a long way in Spain. This has been evidenced in comparative gender and language studies such as that of Francesconi (2012). He compares language reform attempts in Spanish and Italian and affirms that active feminist movements have propelled some linguistic changes in Spain. The author asserts that in Italy, on the other hand, despite studies on linguistic sexism and pressure from feminist movements no results or linguistic changes have been obtained (cf. ibid.: 142).

Nonetheless, it is still evident that more effort is needed in the attempts made to promote the use of ASL. It is likely that this is mostly due to the fact that some speakers do not agree with the proposals against linguistic sexism which imply that the masculine gender has the female semantic value. Consequently, the conflict between these guidelines and the dictates of Spanish linguistic norms is conceivably one of the factors that create resistance against the adoption and implementation of gender-neutral language.

Furthermore, the following questions could serve as guidelines in the campaign against sexist language: Are speakers apathetic to the topic of linguistic sexism and its effects? Or are speakers uncomfortable with the ASL varieties? Does it obstruct their written and oral communicative abilities? In order to find answers to these questions, it is worth summarising and discussing briefly the ASL elements mentioned above.

The use of generic or collective nouns, periphrasis and metonymic constructions do not conflict with Spanish grammar (i. e. apart from challenging the "double role" (specific and generic) of the masculine gender). Moreover, these suggestions could be used easily since they are less cumbersome. However, it should be remembered that in this case, speakers would need to make enough effort in order to remember the ASL guidelines and to decide how best to insert them into their speech. It is a complete linguistic variety which would need to be "learnt" since in order to comply with them, the language faculty ceases to be instinctive, nonreflexive and involuntary.

In addition, proposal "h" (the use of determinants without gender marking) seems to be quite practical. What remains uncertain is whether it will be possible to completely eradicate the use of determinants with gender marking with the aim of eliminating linguistic sexism. It seems even if it becomes possible to implement this proposal, it would be necessary to fully eradicate (or at least reduce to the very minimum) its use. However, as long as it coexists (as it does now) with sexist varieties, one cannot affirm that the feminist goals of language reform have been achieved with the Spanish language.

Proposals "d" (the use of split forms), "e" (the use of slash sign) and " $\mathrm{f}$ " (the introduction of explicative appositions) are, as it has been indicated, suggestions that are difficult to implement. This is because they make linguistic economy impossible. Roca (2006: 427) describes them as "a very substantial augmentation of verbal prolixity" which is "dysfunctional since more words to say or write, and listen to or read are needed constantly".

Although suggestion " $\mathrm{i}$ " (the use of structures with se) does not conflict with the grammatical norms, it does contravene the principles of communication. In these cases certain linguistic 
nuances that are needed to properly understand discourse are omitted. To use the impersonal eliminates the agent of a discourse, which will lead to much ambiguity. This could, however, be acceptable in some contexts; especially when the referent is already known, when it is not necessary to indicate the agent or when one does not want to indicate the agent for ideological or similar reasons (cf. Fairclough 2003). That said, it would be problematic to adopt it as a general rule. The same applies to suggestions " $\mathrm{j}$ " (the use of certain personal forms of verbs) and "k" (the use of impersonal forms of verbs). As Bengoechea et al. (2009: 55) point out the recurrent use of anti-sexist techniques such as passivation and abstract nouns can create an undesired "impersonal, distant, erudite, scholarly, rigid and leaden effect on the text".

On the other hand, suggestion "g" (the omission of determinants) is ungrammatical and causes complications for Spanish grammar. Nothing in language is fortuitous, irrelevant or unnecessary. The essence of the linguistic system (linguistic economy) does not give room for that. Determinants exist in language because they have a function and a semantic value which allows us to capture nuances of reality and codify them linguistically. In the same way, it helps the hearer to decode the received message. In sum, to suggest that these elements be omitted in order to make women visible is to solve one problem by creating other linguistic and pragmatic concerns.

In addition, the word reform implies the formulation of rules (cf. Bengoechea 2011). Generally, linguistic change occurs as a result of the natural evolution of language. Rules are then described to assist in the process of learning and formalisation. Consequently, it would seem that to try to do this in reverse by introducing rules and requesting that they be applied may conflict with this natural process of language evolution and change. Moreover, although the RAE also prescribes grammatical rules in Spanish, ASL reform appears to be a significant challenge. This is because it seeks to eradicate, through imposition, a phenomenon that has been ingrained in the Spanish language since its inception - that is, the grammatical gender.

This is not to say that the attempts at reforming Spanish towards a more gender-neutral use are or will be futile. It is admittedly a complex and controversial problem due to the pervasive and omnipresent essence of the grammatical gender. However, it is possible. The fact that languages like Oriya and English were once gendered languages and have now succeeded in eroding and losing their grammatical gender systems goes to prove this (cf. Hellinger/Bußmann 2001; Hellinger 2001).

Nonetheless, in order to achieve the elimination of gender discrimination in Spanish, more efficient, realistic, and durable means are needed. First of all, dictates proposed by the RAE are acknowledged and implemented because they have been identified as the authoritative body on the correct use of the Spanish language. Consequently, possible drawbacks that could evolve as a result of the conflict between normative grammar and feminist linguistics should be resolved by creating awareness of the negative effects of linguistic sexism and the need for gender-neutral language.

Fairclough (1989: 4) points out that "the effectiveness of resistance and the realization of change depend on people developing a critical consciousness of domination and its modalities, rather than just experiencing them". Thus, the creation of awareness would subsequently authenticate feminist linguistic proposals and neutralize speakers' indifference to ASL attempts once the stigma of "non-grammaticality" is disassociated from antisexist language. It is 
necessary that speakers develop positive attitudes towards anti-sexist linguistic policies. These language policies can be reinforced if speakers accept and adopt antisexist proposals once they are made aware that prescriptivism is not the ultimate in grammar and that constructive changes can be made for the wellbeing of society as a whole.

\section{$7 \quad$ Limitations}

The difficulty of determining precisely which linguistic samples are anti-sexist has limited the present study. For example, the words quienes 'whoever' and personas 'people' as well as the final phrase of Article 3 - 'they do not deserve such nonsense' - could be a compliance with ASL guidelines. However, it is also possible that their use is coincidental. In other words, the writer could have employed them not because she or he has feminist sensibilities but because the person simply opted for these words. In fact, it becomes even more difficult since those which appear to be anti-sexist are mixed with sexist varieties.

For example, in Article 19 there is an abundance of the masculine generic, especially in the phrase querido joven 'dear youth [male/female]' which is repeated throughout the article. However, it also contains the use of nouns with unmarked gender forms such as la juventud 'the youth' and la gente joven 'young people'. Moreover, the gender-neutral expression el empleo juvenile 'youth employment' could be an example of ASL. Nonetheless, the intention of the writer is difficult to determine. The same applies to the impersonal se in all of the articles examined. They could be conscious anti-sexist adoptions or they could also be coincidental.

In sum, even if the frequency of the use of ASL was low, there were some instances which could have been identified as attempts at using gender-neutral language. This limitation to the study was resolved by measures taken to mitigate the difficulty in determining ASL elements. In addition to the definition of "sexist variants" and "non-sexist variants" previously given, I considered the social and linguistic context as well as Spanish grammatical rules to determine the authorial motive for the use of verbal elements. It was thus necessary to reflect upon these aspects of the context in order to arrive at the intention of the author whose message was being decoded. Furthermore, for the identification of choices and possible reasons why expressions were formulated in certain ways, I drew from Gee's (2005: 15) analytical strategy of listing alternative sentence constructions.

Additionally, this study is a small-scale qualitative and quantitative research project that employed limited data in order to achieve comparable statistical analysis of the textual samples used. As indicated above, the nature of some anti-sexist alternatives makes close reading of the newspaper articles necessary so that other important factors such as context can help in the identification of relevant varieties. This would have been difficult to achieve with a large sample. Thus, it is worth emphasizing that the data is, strictly speaking, only valid for the chosen group of textual samples analysed. The present research is exploratory and does not claim to be conclusive. It would therefore be beneficial to undertake further statistical studies to confirm the results obtained in this exploratory investigation. 


\section{Conclusion}

This research argues that peninsular Spanish has been modified by the anti-sexist linguistic policies introduced by various governing bodies, agencies and institutions. Although one might argue that these changes are minimal, it remains clear that ASL has influenced Spanish and continues to do so. As Roca (2012) asserts, "not only is the wave not ceasing, rather it is increasing: every day or almost one hears a split form from the lips of someone who before refrained from the practice".

All the same, it is important to remember that whilst language and culture are interconnected, language is only one of the many variables of culture. Beliefs, institutions and relationships, among others, all influence our thoughts and behavior. Equally, as humans, we construct language and with language we create our reality. While sexist language can perpetuate sexist attitudes, additional sociocultural, political and religious factors also need to be considered in order to promote the battle against sexism. As Cameron (1992) affirms, the links between language and antisexist campaigns are complex and require additional efforts for the elimination of sexism.

\section{References}

Ayala, Marta Concepción/Guerrero, Susana/Medina, Antonia M. (2002): Manual de Lenguaje Administrativo no Sexista. Málaga: Asociación de Estudios Históricos sobre la Mujer.

Bengoechea, Mercedes (2011): "Non-sexist Spanish Policies: An Attempt Bound to Fail?" Current Issues in Language Planning 12: 35-53.

Bengoechea, Mercedes (2006): "Lento deslizamiento del género gramatical femenino al centro del discurso: Nuevos aires en la identificación de mujeres en la prensa española". Spanish in Context 3/1: 139-157.

Bengoechea, Mercedes (2008): "Lo femenino en la lengua: sociedad, cambio y resistencia normativa. Estado de la cuestión". Lenguaje y Textos 27: 37-68.

Bengoechea, Mercedes et al. (2009): Efectos de las Políticas Lingüistas Antisexistas y Feminización del Lenguaje. Madrid: Instituto de la Mujer.

Bengoechea, Mercedes/Simón, José (2014): "Attitudes of University Students to Some Verbal Anti-Sexist Forms". Open Journal of Modern Linguistics 4: 69-90.

Blaubergs, Maija S. (1980): "An Analysis of Classic Arguments against Changing Sexist Language". Women's Studies Int. Quart. 3: 135-147.

Bosque, Ignacio (2012): "Sexismo lingüístico y visibilidad de la mujer". In: El Pais. http: //cultura.elpais.com/cultura/2012/03/02/actualidad/1330717685_771121.html, accessed March 6, 2012.

Calero Fernández, Maria Ángeles (1999): Sexismo Lingüístico: Análisis y Propuestas Ante la Discriminación Sexual en el Lenguaje. Madrid: Narcea.

Cameron, Deborah (1992): Feminism and Linguistic Theory. New York: Palgrave Macmillan.

Centenera Sánchez-Seco, Fernando (2010): "Desdoblamientos, sustantivos genéricos y otros recursos perceptibles en el ordenamiento jurídico español: ¿Una moda de hoy o un cambio con mañana?" Universitas. Revista de Filosofía, Derecho y Política 11: 59-78.

Council of Europe (1986): Igualdad de Sexos en el Lenguaje. Comisión de Terminología en el Comité Para la Igualdad Entre Mujeres y Hombres Del Consejo de Europa. 
Departamento de la Dona (1987): Recomendaciones para un Uso no Sexista de la Lengua. Valencia: Departamento de la Dona, Consellería de Cultura, Educación y Ciencia de la Generalitat Valenciana.

Díaz Rojo, José Antonio (2000): "Sexismo Léxico: Enfoque Etnolingüístico". Español Actual: Revista de Español Vivo 73: 39-56.

Díaz Rojo, José Antonio (2004): "Lengua, cosmovision y mentalidad colectiva". Tonos digital, 7. http://www.um.es/tonosdigital/znum7/estudios/clengua.htm, accessed march 23, 2012.

Eisenberg, Daniel (1985): "Grammatical Sexism in Spanish". Journal of Hispanic Philology 9: 189-196.

Emakunde Instituto Vasco de la Mujer (1992): El Lenguaje, Instrumento de Progreso. Vitoria-Gastliz: Emakunde Instituto Vasco de la Mujer.

Fairclough, Norman (1989): Language and Power. New York: Longman.

Fairclough, Norman (2003) Analysing Discourse: Textual Analysis for Social Research. London and New York: Routledge.

Francesconi, Armando (2012): "El Sexismo en el Lenguaje Político Español e Italiano". Nómadas. Revista Crítica de Ciencias Sociales y Jurídicas 34/2: 139-147.

García Meseguer, Álvaro (1994): ¿Es Sexista la Lengua Española? Una Investigación Sobre el Género Gramatical. Barcelona: Ediciones Paidós Ibérica.

Gee, James Paul (2005): An Introduction to Discourse Analysis: Theory and Method. New York: Routledge.

Grice, Herbert Paul (1967): "Logic and Conversation". In: Cole, Peter/Morgan, Jerry (eds.): Syntax and Semantics 3: Speech Acts. New York, Academic Press: 41-58.

Grice, Herbert Paul (1989): Studies in the Way of Words. Cambridge: Harvard University Press.

Guerrero Salazar, Susana (2007): "Esbozo de una Bibliografía Crítica sobre Recomendaciones y Guías Para un Uso Igualitario del Lenguaje Administrativo". In: Medina Guerra, Antonia Maria (ed.): Avanzando Hacia la Igualdad. Málaga, Diputación de Málaga \& AEHSM: 109-122.

Hellinger, Marlis (2001): "English - Gender in a Global Language". In: Hellinger, Marlis/Bußmann, Hadumod (eds.): Gender Across Languages: The Linguistic Representation of Women and Men. Volume I. Amsterdam, John Benjamins: 105-113.

Hellinger, Marlis/Bußmann, Hadumod (eds.) (2001): Gender across Languages: The Linguistic Representation of Women and Men. Volume I. Amsterdam: John Benjamins.

Hellinger, Marlis/Bußmann, Hadumod (eds.) (2002): Gender across Languages. Volume 2. Philadelphia: John Benjamins Company.

Heredero, Carmen (2007): "Las mujeres y el lenguaje: un amor no correspondido". In: Heredero de Pedro, Carmen/Muñoz Hernández, Esther (eds.): Incorporamos el Lila al Currículo Educativo: Las Mujeres También Cuentan: VI Encuentros de las Secretarías de la Mujer 16, 17 y 18 de mayo de 2007. Madrid, Paralelo Edición: 75-91.

Jiménez Rodrigo, María Luisa/Onsalo, Marisa Román/Cortes, Joaquín Traverso (2011): "Lenguaje no Sexista y Barreras a su Utilización. Un Estudio en el Ámbito Universitario". Revista de Investigación en Educación 9: 174-183.

Kvale, Steinar (ed.) (2008): Doing Interviews. Thousand Oaks, California: SAGE.

Lakoff, Robin (1995): El Lenguaje y el Lugar de la Mujer. Barcelona: Editorial Hacer.

ISSN 1615-3014 
Lemus, Jorge E. (2001): "Sexismo en el Lenguaje: Mitos y Realidades". In: Rivas, Ramòn et al. (eds.): Memorias del Encuentro de la Red Centroamericana de Antropología. San Salvador, Universidad Tecnológica: 195-225.

Lledó, Eulàlia (1992): El Sexismo y el Androcentrismo en la Lengua: Análisis y Propuestas de Cambio. Barcelona: ICE de la UAB.

López, Elsa (2013): “Cuerpos de mujer”. La Opinión. http://www.laopinion.es/opinion/2013/02/12/cuerpos-mujer/459241.html, accessed february $12,2013$.

Nissen, Uwe Kjær (2002): "Gender in Spanish: Tradition and Innovation". In: Hellinger, Marlis/Bußmann, Hadumod (eds.): Gender across Languages: The Linguistic Representation of Women and Men. Volume 2. Amsterdam, John Benjamins: 251-279.

Nissen, Uwe Kjær (2013): "Is Spanish Becoming more Gender Fair? A Historical Perspective on the Interpretation of Gender-specific and Gender-neutral Expressions". Linguistik Online 58: 99-117.

Perissinotto, Giorgio (1983): "Spanish hombre: Generic or specific?" Hispania 66/4: 581586.

Pauwels, Anne (1998): Women changing language. London: Longman.

Pauwels, Anne (1999): "Feminist Language Planning: Has it been worthwhile?" Linguistik Online 2: 1-10.

Pauwels, Anne (2003): "Linguistic Sexism and Feminist Linguistic Activism". In: Holmes, Janet/Meyerhoff, Miriam (eds.) The Handbook of Language and Gender. Massachusetts, Blackwell Publishing: 550-570.

Prewitt-Freilino, Jennifer L./Caswell, Andrew T./Laakso, Emmi K. (2012): "The Gendering of Language: A Comparison of Gender Equality in Countries with Gendered, Natural Gender, and Genderless Languages". Sex Roles 66: 268-281.

Roca, Ignacio (2006): "La Gramática y la Biología en el Género del Español". Revista Española de Lingüística 2: 397-432.s

Roca, Ignacio (2012): "El Nuevo Año y su Primer Nacimiento: Sexo y Género". Fundación del español urgente. http://www.fundeu.es/noticias-articulos-el-nuevo-ano-y-su-primernacimiento-sexo-y-genero-6857.html, accessed August 6, 2013.

Rodríguez Fernández, María (2009): La Evolución del Género Gramatical Masculino como Término Genérico: su Reflejo en la Prensa Contemporánea. Madrid: Fundamentos.

Segalás, Alejandro (2013): "Las madres zurcen las redes sociales". La Gaceta de Salamanca. http://www.lagacetadesalamanca.es/alejandro-segalas/2013/01/16/madres-zurcen-redessociales/83461.html, accessed february 11, 2013.

Sperber, Dan/Deirdre, Wilson (1995): Relevance: Communication and Cognition. Oxford: Blackwell.

UNESCO (1990): Recomendaciones Para un Uso no Sexista de la Lengua. Paris: UNESCO.

Velasco, María Luisa/Vázquez, Diana/Ibáñez, Marta (2009): El Cambio Lingüístico en la Educación en los Últimos Años en España. Madrid: Instituto de la Mujer.

Wasserman, Benjamin D./Weseley, Allyson J. (2009): "¿Qué? Quoi? Do Languages with Grammatical Gender Promote Sexist Attitudes?" Sex Roles 61: 634-643. 